Vol. 1 No. 3 November 2021 e-ISSN : 2797-1031 | p-ISSN : 2797-0744

\title{
PENINGKATAN KEMAMPUAN ABSTRAKSI MATEMATIS SISWA SMPN 16 BANDUNG MELALUI PEMBELAJARAN DENGAN MODEL ELICITING ACTIVITIES (MEAS)
}

\author{
EVA APRIYANI \\ Pascasarjana PMIPA, Universitas Indraprasta PGRI, Jakarta \\ e-mail: evaapriany123@gmail.com
}

\begin{abstract}
ABSTRAK
Kemampuan abstraksi dalam matematika sangat penting karena dapat digunakan untuk menggambarkan konsep matematis dalam sebuah permasalahan matematis. Salah satu cara untuk membantu siswa menumbuh kembangkan kemampuan abstraksi matematis adalah dengan menerapkan Model Eliciting Activities (MEAs). Tujuan dari penelitian ini adalah untuk mengetahui peningkatan kemampuan abstraksi matematis antara siswa yang mendapatkan pembelajaran matematika dengan MEAs dibandingkan dengan model ekspositori, dan mengetahui sikap siswa terhadap pembelajaran matematika dengan MEAs. Metode yang digunakan pada penelitian ini adalah kuasi eksperimen. Populasi pada penelitian ini adalah siswa kelas VIII SMP Negeri 16 Bandung dengan sampel dua kelas dari keseluruhan kelas VIII yang tersedia. Instrumen yang digunakan adalah instrumen tes kemampuan abstraksi matematis, angket, lembar observasi, dan jurnal harian siswa. Hasil penelitian menunjukkan bahwa peningkatan kemampuan abstraksi matematis dengan MEAs lebih baik dari pada siswa yang mendapatkan pembelajaran matematika dengan model ekspositori,. Selain itu, siswa memberikan respons yang positif terhadap pembelajaran matematika dengan MEAs.
\end{abstract}

Kata Kunci: Kemampuan Abstraksi Matematis, Model Eliciting Activities (MEAs)

\begin{abstract}
Abstraction ability in mathematics is very important because it can be used to describe mathematical concepts in a mathematical problem. One way to help students develop mathematical abstraction skills is to apply the Eliciting Activities Model (MEAs). The purpose of this study was to determine the increase in mathematical abstraction skills between students who received mathematics learning with MEAs compared to the expository model, and to determine students' attitudes towards mathematics learning with MEAs. The method used in this research is quasi-experimental. The population in this study were students of class VIII SMP Negeri 16 Bandung with a sample of two classes from all available class VIII. The instruments used are mathematical abstraction ability test instruments, questionnaires, observation sheets, and students' daily journals. The results showed that the improvement of mathematical abstraction skills with MEAs was better than students who received mathematics learning using the expository model. In addition, students gave a positive response to learning mathematics with MEAs.
\end{abstract}

Keywords: Mathematical Abstraction Ability, Eliciting Activities Model (MEAs)

\section{PENDAHULUAN}

Kemampuan abstraksi dalam matematika sangat penting karena merupakan suatu kemampuan untuk menggambarkan konsep matematis dengan kata lain abstraksi dapat membangun model situasi masalah (Yuliati, 2013). Berdasarkan teori perkembangan berpikir anak oleh Piaget yang menjelaskan bahwa pada tahap umur anak SMP ini seharusnya anak sudah menguasai kemampuan abstraksi dengan baik. Namun, pada kenyataannya kemampuan abstraksi yang dimiliki siswa rendah. Hal itu dapat dilihat dari nilai hasil belajar siswa yang kurang baik. Di samping itu, hasil survey PISA (programme for International student asessment) 2012 menyatakan bahwa Indonesia menduduki peringkat ke 64 dari 65 negara yang di survey, dengan skor rata-rata Indonesia yaitu 375 masih di bawah skor rata-rata yaitu 494. 
Contoh sederhana yang mengilustrasikan keabstrakan objek kajian matematika salah satunya dapat ditemukan pada konsep bilangan pada aljabar. Misalnya bilangan 3 pada hakikatnya adalah konsep abstrak. Konsep 'tiga' sebagai bilangan akan bermakna jika dikaitkan dengan objek seperti tiga buah jeruk, tiga buah buku, dan lain-lain. Adapun representasi simbolnya berupa 3 adalah sesuatu yang real.

Berdasarkan ilustrasi di atas, tidak berlebihan apabila matematika sering disebut sebagai mata pelajaran yang abstrak. Hal ini berbeda dengan pemikiran siswa yang terbiasa dengan berpikir tentang objek-objek yang konkret. Tidak heran banyak sekali siswa yang mengalami kesulitan dalam upaya memahami matematika. Padahal seharusnya berdasarkan teori taraf berpikir siswa SMP harus sudah menguasai kemampuan abstraksi. Menurut Mitchelmore \& White (2007) mengemukakan bahwa abstraksi adalah "Making connections between ideas, facts, or procedures". Selain itu, menurut Yuliati (2013) menjelaskan bahwa abstraksi merupakan kemampuan menemukan pemecahan masalah matematika tanpa hadirnya objek permasalahan itu secara nyata". Menurut Nurhasanah (2010) siswa bisa dikatakan telah memiliki kemampuan abstraksi jika siswa tersebut telah mampu untuk (1) Mengidentifikasi karakteristik objek melalui pengalaman langsung, (2) Mengidentifikasi karakteristik objek yang dimanipulasi atau diimajinasikan, (3) Merepresentasikan gagasan matematis dalam bahasa dan simbol matematika, (4) Melepaskan sifat-sifat kebendaan dari sebuah objek atau melakukan idealisasi, (5) Membuat hubungan antar proses atau antar konsep untuk membentuk pengertian baru, (6) Mengaplikasikan konsep pada konteks yang sesuai, (7) Melakukan manipulasi objek matematis yang abstrak. Dengan demikian, dibutuhkan suatu proses pembelajaran yang jelas, agar siswa dapat memahami objek-objek kajian yang abstrak dalam matematika. Lebih lanjut, Nurhasanah (2010) mengemukakan bahwa proses pembelajaran tersebut hendaknya merupakan proses yang mengantarkan siswa melakukan dan mengalami kegiatan-kegiatan ke arah pembentukan konsep yang abstrak. Secara sederhana, proses ini disebut sebagai proses abstraksi.

Melihat kondisi pembelajaran matematika yang seperti ini, maka perlu adanya inisiatif dari guru dalam memilih pendekatan yang tepat dalam melaksanakan pembelajaran matematika di kelas. Hal ini bertujuan agar pembelajaran matematika dapat lebih berkualitas dan terasa menyenangkan sehingga tujuan pembelajaran dapat tercapai dan di perkirakan mampu meningkatkan kemampuan abstraksi siswa.

Salah satu pendekatan yang dapat diterapkan untuk meningkatkan kemampuan abstraksi siswa adalah dengan Model eliciting activities (MEAs). Chamberlin \& Moon (2005) menyatakan bahwa Model Eliciting Activities (MEAs) adalah pembelajaran yang mendorong siswa untuk menciptakan model matematika. Sejalan dengan itu, menurut Permana (2010) menjelaskan bahwa Model Eliciting activities (MEAs) adalah model pembelajaran untuk memahami, menjelaskan dan mengomunikasikan konsep-konsep yang terkandung dalam suatu sajian melalui proses pemodelan matematika. Jadi, Pendekatan MEAs adalah pendekatan pembelajaran untuk memahami, menjelaskan, dan mengomunikasikan konsep-konsep yang terkandung dalam suatu sajian masalah melalui proses pemodelan matematika. Model pembelajaran MEAs ini ada empat tahap yaitu: (1) Mengidentifikasi dan menyederhanakan situasi masalah, (2) Membangun model matematis, (3) Mentransformasi dan menyelesaikan model, (4) Menginterpretasi hasil (Permana, 2010).

Salah satu prinsip pembelajaran dengan Model Eliciting activities (MEAs) adalah permasalahan yang disajikan dalam pembelajaran merupakan permasalahan yang realistik. Sebagaimana disampaikan oleh Lesh yaitu "making the problem a realistic one defining characteristic of MEAs" (Chamberlin \& Moon, 2005). Melalui penyajian permasalahan yang realistis di harapkan dapat memunculkan ketertarikan siswa dan di harapkan siswa dapat dengan mudah memahami permasalahan karena dekat dengan kehidupan sehari-hari siswa. Mudahnya memahami permasalahan yang di berikan, di harapkan siswa dapat lebih mudah merepresentasikan gagasan matematika ke dalam bahasa dan simbol matematika, melepaskan sifat-sifat kebendaan dari suatu objek, serta mengaplikasikan konsep pada konteks yang sesuai. 
Karena adanya sajian permasalahan sehingga siswa diminta untuk menerjemahkan permasalahan yang ada dengan kata-kata sendiri. Dengan menghasilkan model matematis sebagai solusi siswa dilatih untuk menerjemahkan permasalahan ke dalam bentuk model matematis. Kemudian siswa diminta untuk menyelesaikan model dengan konsep pada konteks yang materi pada matematika, seperti mebuat model penyelesaian permasalah menghitung kesamaan ketika akan bertemu lagi saat bertemu sebelumnya, memodelkan permasalahan terkait kesamaan harga dalam membeli dua barang atu lebih dan lain sebagainya.

Berdasarkan uraian di atas, terdapat beberapa permasalahan yang muncul. Untuk menjawab hal tersebut, maka perlu dilakukan penelitian dengan tujuan untuk mengetahui: (1) Apakah peningkatan kemampuan abstraksi matematis siswa yang mendapat pembelajaran matematika dengan model eliciting activities (MEAs) lebih baik dari pada pembelajaran matematika dengan pendekatan ekspositor (2) Bagaimana sikap siswa terhadap pembelajaran matematika dengan menggunakan Model eliciting activities (MEAs)

\section{METODE PENELITIAN}

Metode yang digunakan dalam penelitian ini adalah kuasi eksperimen dengan desain penelitian kelompok kontrol pretest-postest sebagai berikut.

$$
\mathrm{O} \mathrm{X}_{1} \mathrm{O}
$$

Keterangan:

$\mathrm{O}:$ Tes (pretes atau postes)

$\mathrm{X}_{1}$ : Pembelajaran matematika dengan MEAs

$\mathrm{X}_{2}$ : Pembelajaran matematika dengan ekspositori

Populasi dari penelitian ini adalah siswa kelas VIII SMP Negeri 16 Bandung. Sampel penelitian diambil dua kelas secara acak. Namun oleh karena tidak memungkinkan untuk mengubah kelas yang telah ada, maka diambil dua kelas yang memiliki karakteristik yang hampir sama, pemilihan dua kelas tersebut berdasarkan hasil wawancara dengan guru di sekolah tersebut dan observasi pendahuluan ke sekolah. Satu kelas digunakan sebagai kelas eksperimen, yang diberikan pendekatan pembelajaran dengan model eliciting activities (MEAs) yaitu kelas VIII-8 Sedangkan satu kelas lagi sebagai kelas kontrol, diberikan pembelajaran ekspositori yaitu kelas VIII-7.

Mengenai ukuran sampel untuk penelitian eksperimen, maka ukuran sampel yang harus diambil minimal 30 siswa/kelompok. Setiap kelas VIII SMP Negeri 16 Bandung jumlah siswanya rata-rata 36 siswa, berarti memenuhi ukuran sampel yang harus dipenuhi. Instrumen penelitian yang digunakan adalah instrumen tes kemampuan abstraksi matematis, angket skala sikap, lembar observasi dan jurnal hariam. Angket skala sikap digunakan untuk mengungkap sikap siswa terhadap penerapan model pembelajaran MEAs. Adapun lembar observasi disusun untuk mencatat aktivitas apa saja yang berlangsung selama proses pembelajaran sehingga dapat memberikan gambaran tentang situasi belajar di kelas yang sesungguhnya. Sedangkan jurnal harian digunakan untuk mengetahui respons siswa selama pembelajaran dengan MEAs.

\section{HASIL DAN PEMBAHASAN}

\section{Hasil}

Data yang dihasilkan dari penelitian ini berupa data kuantitatif dan data kualitatif. Data kuantitatif diperoleh dari data skor pretes, postes, dan data angket. Pengolahan data kuantitatif dilakukan menggunakan software SPSS versi 18.0. adapun data kualitatif diperoleh dari hasil observasi dan jurnal harian siswa.

Secara umum, deskripsi tentang kemampuan abstraksi matematis siswa berdasarkan data mentah yang diperoleh dari hasil pretes dan postes ditunjukkan dalam tabel 1 berikut ini. 
Tabel 1. Data Statistik deskriptif pretes dan postes Kemampuan abstraksi matematis Pretes Postes

\begin{tabular}{lcccc} 
& Eksp. & Kontr. & Eksp, & Kontr. \\
\hline Min & 0.000 & 0.000 & 32.000 & 5.000 \\
\hline Maks & 45.000 & 85.000 & 100.000 & 95.000 \\
\hline Mean & 8.583 & 9.028 & 72.000 & 44.722 \\
\hline $\begin{array}{l}\text { Std. } \\
\text { deviation }\end{array}$ & 13.291 & 15.798 & 19.223 & 23.548 \\
\hline
\end{tabular}

Peningkatan kemampuan abstraksi matematis siswa beserta kualitasnya dapat dilihat dari hasil perhitungan indeks N-gain. Berdasarkan skor pretes dan postes yang siswa peroleh, dapat diketahui indeks $\mathrm{N}$-gain dari masing-masing siswa. Berikut ini akan disajikan statistik deskriptifnya.

Tabel 2. Data Hasil Uji Statistik Deskriptif Indeks N-Gain Kemampuan Abstraksi Matematis

\begin{tabular}{lrrrrr}
\hline & & & & \multicolumn{2}{c}{ Std. } \\
& $\mathrm{N}$ & Min & Max & Mean & Dev \\
\hline gainek & 36 &, 04 & 1,000 &, 6859 &, 2259 \\
sp & & 8 & & 2 & 2 \\
\hline gainko & 36 & - &, 860 &, 4002 &, 2309 \\
ntr & & 05 & & 8 & 0 \\
& & 0 & & & \\
\hline Valid & 36 & & & & \\
N & & & & & \\
(listwi & & & & & \\
se) & & & & & \\
\hline
\end{tabular}

Perolehan skor indeks N-gain rata-rata siswa dapat di interpretasikan ke dalam kategori tinggi, sedang atau rendah. Dari hasil perhitungan menggunakan bantuan software Microsoft excel 2007, rata-rata skor indeks N-gain masing-masing kelas disajikan dalam tabel berikut.

Tabel 3. Data Hasil Uji Indeks N-Gain Berdasarkan Rata-Rata Kelas

\begin{tabular}{lcc}
\hline & $\begin{array}{c}\text { Rata-rata } \\
\text { IG }\end{array}$ & Kategori \\
\hline Kel eksp & 0,686 & Sedang \\
\hline Kel kont & 0,400 & Sedang \\
\hline
\end{tabular}

Berdasarkan Tabel 3 di atas kedua kelas mengalami peningkatan dalam kategori sedang. Adapun untuk mengetahui perolehan skor indeks N-gain tiap siswa pengelompokannya disajikan dalam tabel berikut ini.

Tabel 4. Data Hasil Uji Indeks N-Gain Kemampuan Abstraksi Matematis Siswa

\begin{tabular}{ccccc}
\hline Kelas & $\begin{array}{c}\text { Indeks N- } \\
\text { Gain }\end{array}$ & Kategori & $\begin{array}{c}\text { Frekuensi } \\
\text { Siwa }\end{array}$ & $\begin{array}{c}\text { Persentase } \\
(\boldsymbol{\%})\end{array}$ \\
\hline Ekspe & $\begin{array}{c}\text { Indeks N- } \\
\text { gain }>0,70\end{array}$ & tinggi & 21 & 58,333 \\
\cline { 2 - 5 } & $\begin{array}{c}0,30<\text { indeks } \\
\text { N- } \\
\text { gain } \leq 0,70\end{array}$ & sedang & 12 & 33,333 \\
& $\begin{array}{llll}\text { Indeks N- } \\
\text { gain } \leq 0,30\end{array}$ & rendah & 3 & 8,333 \\
\hline Kontl & $\begin{array}{c}\text { Indeks N- } \\
\text { gain }>0,70\end{array}$ & tinggi & 3 & 8,333 \\
\hline
\end{tabular}




\begin{tabular}{cccc}
\hline $\begin{array}{c}0,30<\text { indeks } \\
\mathrm{N}-\end{array}$ & sedang & 19 & 52,778 \\
gain $\leq 0,70$ & & & \\
\hline $\begin{array}{c}\text { Indeks N- } \\
\text { gain } \leq 0,30\end{array}$ & rendah & 14 & 38,889 \\
\hline
\end{tabular}

\section{Pembahasan}

Berdasarkan Tabel 1 di atas, dapat diketahui pada data pretes, skor minimum kelas eksperimen adalah 0 dan skor minimum pada kelas kontrol juga adalah 0 . Hal ini menunjukkan bahwa skor minimum kelas eksperimen dan kelas kontrol adalah sama. Namun untuk melihat apakah kemampuan abstraksi matematis awal kelas eksperimen dan kelas kontrol memiliki perbedaan yang signifikan atau tidak, maka harus dilakukan uji perbedaan dua rata-rata menggunakan uji Mann-Whitney $U$ dengan taraf signifikansi 5\%. Melalui uji hipotesis dengan perumusan $H_{0}$ dan $H_{1}$ sebagai berikut:

$H_{0}$ : tidak ada perbedaan kemampuan abstraksi matematis awal siswa kelas yang menggunakan pembelajaran MEAs dan kelas yang menggunakan pembelajaran ekspositori.

$H_{1}$ : ada perbedaan kemampuan abstraksi matematis awal siswa kelas yang menggunakan pembelajaran MEAs dan kelas yang menggunakan pembelajaran ekspositori.

Diperoleh nilai signifikansi $=0,727>\alpha=0,05$ sehingga $H_{0}$ diterima. Berarti bahwa tidak terdapat perbedaan kemampuan abstraksi matematis awal yang signifikan antara siswa kelas eksperimen dengan siswa kelas kontrol. Setelah diperoleh kesimpulan bahwa kemampuan awal yang dimiliki oleh kedua kelas adalah sama, langkah berikutnya adalah melakukan analisis terhadap data indeks $\mathrm{N}$-gain untuk melihat pencapaian kemampuan abstraksi matematis akhir kedua kelas penelitian.

Dari Tabel 2 dapat diketahui bahwa rata-rata indeks N-gain kelas eksperimen lebih tinggi daripada rata-rata indeks $\mathrm{N}$-gain kelas kontrol. Namun untuk mengetahui apakah perbedaan peningkatan kemampuan abstraksi matematis kedua kelas signifikan atau tidak, maka dilakukan uji statistik terhadap data indeks $\mathrm{N}$-gain. Berdasarkan hasil uji perbedaan dua rata-rata, diperoleh nilai Sig $=0,000<\alpha=0,05$. Hal ini menunjukkan bahwa $H_{0}$ ditolak, yang berarti bahwa kualitas peningkatan kemampuan abstraksi matematis siswa kelas eksperimen lebih tinggi daripada siswa kelas kontrol.

Berdasarkan deskriptif data tersebut, dapat dilihat bahwa siswa kelas eksperimen memiliki kualitas peningkatan kemampuan abstraksi matematis yang lebih tinggi dari pada kelas kontrol. Hal ini sejalan dengan uji statistik mengenai indeks $\mathrm{N}$-gain yang telah dilakukan pada bagian sebelumnya, bahwa peningkatan kemampuan abstraksi matematis siswa yang memperoleh pembelajaran dengan model Eliciting activities (MEAs) lebih tinggi di bandingkan siswa yang memperoleh pembelajaran dengan metode ekspositori, yang diiringi kualitas peningkatan yang lebih tinggi pula.

Penerapan model pembelajaran MEAs tentu memunculkan kesan tersendiri bagi setiap siswa. Oleh karena itu, untuk mengetahui sikap siswa terhadap model pembelajaran MEAs, peneliti menggunakan angket skala sikap dari Likert. Dari hasil pengolahan data angket dapat diketahui bahwa sebanyak 73,8\% dari jumlah keseluruhan siswa kelas eksperimen bersikap positif terhadap penerapan model pembelajaran MEAs. Hal ini didukung oleh hasil respons siswa melalui jurnal harian. Pada pertemuan pertama sebanyak 63,3 \% berkomentar positif, pada pertemuan kedua naik menjadi $86 \%$ yang berkomentar positif, dan pada pertemuan ketiga sebanyak $63,3 \%$ yang berkomentar positif.

Berdasarkan hasil observasi selama kegiatan pembelajaran di kelas eksperimen berlangsung, secara umum dapat dikatakan bahwa pembelajaran berlangsung dengan baik dan sistematik. Hal yang perlu dipertimbangkan dengan baik sebelum pelaksanaan pembelajaran adalah durasi waktu yang tepat. Hal ini dikarenakan pembelajaran di kelas eksperimen menuntut siswa untuk berperan aktif selama pembelajaran sehingga membutuhkan waktu yang 
lebih lama dibandingkan dengan pembelajaran melalui metode ekspositori. Adapun proses keterlaksanaan pembelajaran di kelas kontrol secara umum juga sudah berlangsung dengan baik. Perbedaan antara perlakuan yang diberikan pada kelas eksperimen dan kelas kontrol hanya terletak pada kegiatan inti selama pembelajaran dilakukan. Sedangkan soal latihan yang diberikan di kelas kontrol juga sama dengan soal-soal yang diberikan untuk kelas eksperimen, sehingga siswa kedua kelas sama-sama memperoleh pengalaman untuk mengerjakan tipe soal yang mengukur kemampuan komunikasi matematik siswa. Hal ini sesuai dengan hasil penelitian Fadhiya tahun 2016 pada penelitian penerapan pendekatan model-eliciting activities terhadap kemampuan pemecahan masalah matematika siswa SMP dengan hasil terdapat peningkatan dengan rata rata pretes sebesar 13,83 dan rata rata posttes sebesar 28,46 pada kelas kelas eksperimen, sedangakan pada kelas kontrol sebesar pretes sebesar 16,01dan rata rata posttes sebesar 16,01. Selain itu sesuai juga dengan hasil penelitian Abdul Rosyidl tahun 2018 pada penelitian peningkatan kemampuan pemecahan masalah matematis siswa melalui pendekatan Model-Eliciting Activities (MEAs) terdapat peningkatan dengan hasil rata-rata NGain kelas eksperimen 0,38 dan rata-rata N-Gain kelas kontrol 0,25. Selanjutnya rata-rata NGain kelas eksperimen kelompok kemampuan awal matematis tinggi 0,55; kelompok kemampuan awal matematis sedang 0,34; kelompok kemampuan awal matematis rendah 0,39 . Sedangkan rata-rata $\mathrm{N}$-Gain kelas kontrol kemampuan awal matematis tinggi 0,32; kelompok kemampuan awal matematis sedang 0,24; kelompok kemampuan awal matematis rendah 0,27.

\section{KESIMPULAN} berikut.

Berdasarkan hasil analisis data dan pembahasan, maka diperoleh kesimpulan sebagai

1. Peningkatan kemampuan abstraksi matematis siswa yang mendapatkan pembelajaran matematika dengan model Eliciting activities (MEAs) lebih tinggi daripada peningkatan kemampuan Abstraksi matematis siswa yang menggunakan metode ekspositori.

2. Siswa bersikap positif terhadap pembelajaran matematika dengan menggunakan model Eliciting activities (MEAs).

\section{DAFTAR PUSTAKA}

Chamberlin, \& Moon. (2005). Model-Eliciting Activities as a Tool to Develop and Identify Creatively Gifted Mathematicians. University of Wyoming. ], XVII(1), 37-47.

Chotimah, S, Ramdhani, F A, Martin Bernard, M, Akbar, P.(2019). Pengaruh Pendekatan Model-Eliciting Activities Terhadap Kemampuan Berpikir Kritis Matematik Siswa SMP Negeri Di Kota Cimahi. Journal On Education Volume 01, No. 02, Februari, hal. 68-77.

Fadhiya, F., Yuliardi, R., \& Rosyid, A. (2016). Penerapan Pendekatan Model-Eliciting Activities Terhadap Kemampuan Pemecahan Masalah Matematika Siswa Smp. Jumlahku: Jurnal Matematika Ilmiah STKIP Muhammadiyah Kuningan, 2(2), 67-73. from http://jurnal.upmk.ac.id/index.php/jumlahku/article/view/312

Kementrian pendidikan dan kebudayaan (2013). Skor PISA: Posisi Indonesia Nyaris Jadi Juru Kunci. [Online]. Tersedia: http://www.kopertis12.or.id/2013/12/05/skor-pisa-posisiindonesia-nyaris-jadi-juru-kunci.html. [11 Mei 2014]

Mitchelmore, M., \& White. (2007). Abstractoin in mathematics Learning. Mathematics Education Journal, 19(2), 1-9.

Nurhasanah, F. (2010). Abstraksi Siswa SMP dalam Belajar Geometri Melalui Penerapan Model Van Hiele dan Geometers 'Sketchpad (yunior high school student' abstraction in learning geometry through van hiele's model and geometers' sketchpad). Universitas Pendidikan Indonesia.

Permana, Y. (2010). Mengembangkan Kemampuan Pemahaman, Komunikasi dan Disposisi Matematis Siswa SMA Melalui Model Eliciting Activities. Disertasi SPS Universitas Pendiidikan Indonesia. 
Rosyid1, Abdul dan Fadhiya.(2018). Peningkatan Kemampuan Pemecahan MasalahMatematis Siswa Melalui Pendekatan Model-Eliciting Activities (MEAs). Jurnal THEOREMS (The Original Research of Mathematics). Vol. 2 No. 2, Januari 2018 hal. 33-41

Yuliati, A. (2013). Penerapan Pendekatan Concrete-Representational-Abstract (CRA) untuk Meningkatkan Kemampuan Abstraksi Matematis Siswa Sekolah Menengah Pertama (SMP) Dalam Belajar Geometri. Universitas Pendidikan Indonesia. 